\title{
UPLATNENIE METODIKY BSC PRI VYTVÁRANÍ STRATÉGIE RIADENIA LUDSKÝCH ZDROJOV V SLOVENSKEJ POŠTE, A. S.
}

\author{
Kamila Jandzíková ${ }^{1}$, Mariana Strenitzerová ${ }^{2}$
}

\section{1. Úvod}

Príspevky publikované $\mathrm{v}$ predchádzajúcich dvoch číslach časopisu boli venované analýze súčasného stavu strategického riadenia l'udských zdrojov a konceptu vytvárania stratégie riadenia l'udských zdrojov v podmienkach Slovenskej pošty, a. s. (SP, a.s.). Dnešný príspevok je venovaný uplatneniu metodiky BSC pri vytváraní stratégie riadenia l'udských zdrojov v SP, a. S.. Uvedenú metodiku sme použili pri návrhu konceptu merania výkonnosti úseku l'udských zdrojov.

V mnohých podnikoch sa ako účinný nástroj strategického riadenia využíva metodika Balanced Scorecard (BSC). SP, a. s. sa pri koncipovaní novej stratégie riadenia l'udských zdrojov rozhodla vychádzat' práve z uplatnenia tejto metódy. BSC vnáša svetlo do 4 oblastí: financie, zákazníci, personál, procesy/systémy. Zapája do hry aj oblast' l'udských zdrojov. BSC je založená na jednoducho meratel'ných veličinách, ktoré zrozumitel'ným spôsobom vypovedajú o všetkom podstatnom. Táto prednost' BSC môže byt' využitá i v samotnej oblasti l'udských zdrojov. Pomocou vhodne zvolených ukazovatel'ov môže byt' strategicky významná výkonnost' l'udských zdrojov preložená do zrozumitel'ných podnikatel’ských termínov.

\section{Návrh konceptu merania výkonnosti úseku l'udských zdrojov - Human Resources Balanced Score Card (HR BSC)}

Navrhnutý koncept merania výkonnosti úseku l’udských zdrojov má slúžit' ako určitá spätná väzba. Presné definovanie HR indikátorov (KPI - Key Performance Indicators) umožní poštovému podniku vyhodnotit' správnost' konania pri plnení určitých strategických ciel'ov, ako aj v závere vyhodnotit' účinnost' a efektívnost' implementácie navrhnutej stratégie.

Navrhnuté strategické ciele úseku l'udských zdrojov sú definované v rámci štyroch základných perspektív metodiky BSC (finančná perspektíva, zákaznícka perspektíva, perspektíva interných procesov, perspektíva učenia sa a rastu). Určením vzájomných vzt'ahov a väzieb medzi jednotlivými ciel’mi bola vytvorená tzv. strategická mapa (obr. 1).

\footnotetext{
${ }^{1}$ Mgr. Kamila Jandzíková, Slovenská pošta, a.s., Partizánska cesta 9, 97599 Banská Bystrica, Slovenská republika tel. 00421-048-433 92 06, fax 00421-048-411 52 13, e-mail: jandzikova.kamila@slposta.sk

${ }^{2}$ doc. Ing. Mariana Strenitzerová, PhD., Žilinská Univerzita v Žiline, Fakulta prevádzky a ekonomiky dopravy a spojov, Katedra spojov, Univerzitná 1, 01026 Žilina, Slovenská republika tel. 00421-041-5133 131, fax 00421-041-5655 615, e-mail: Mariana.Strenitzerova@fpedas.uniza.sk
} 


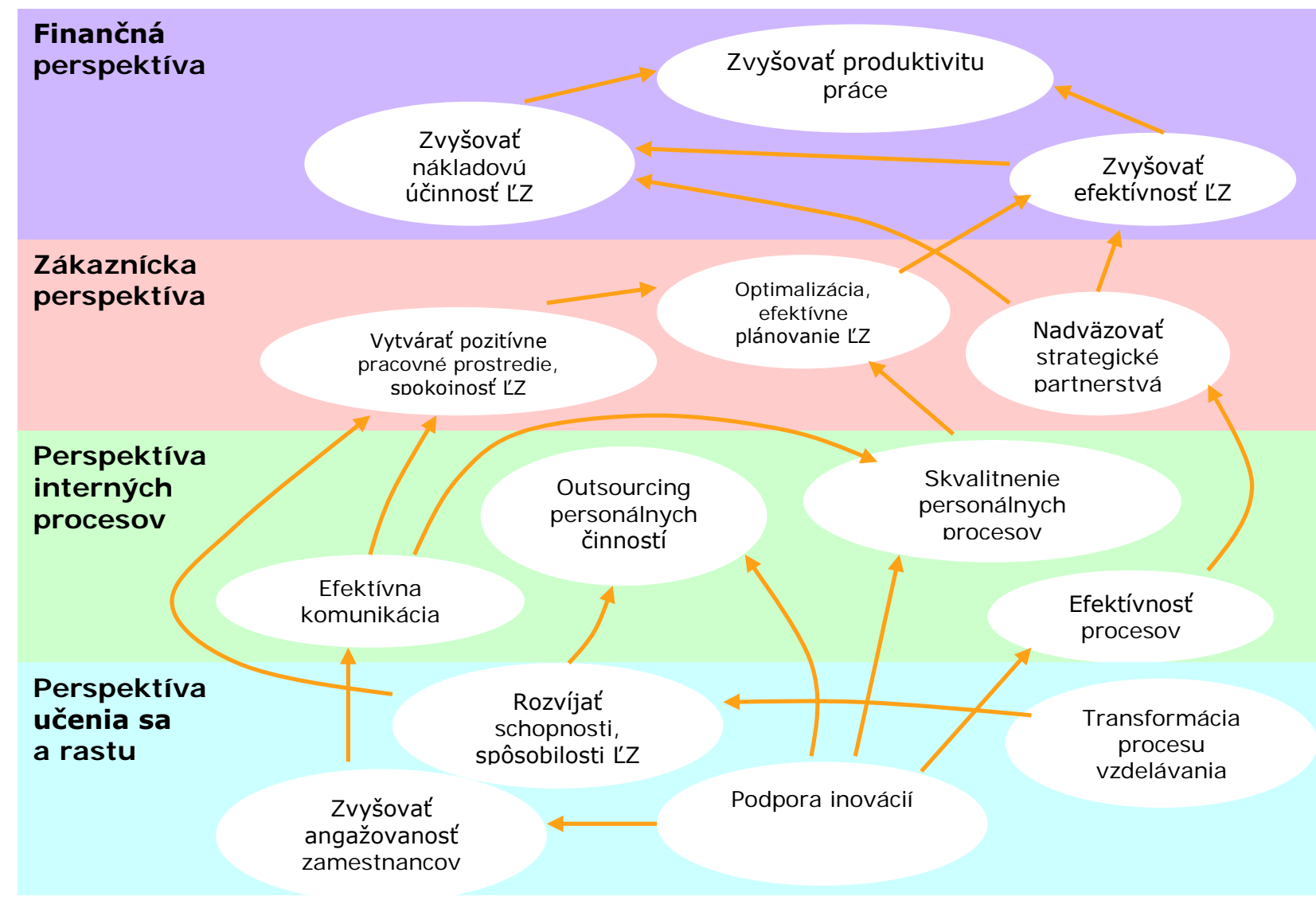

Obr. 1: Strategická mapa riadenia l'udských zdrojov v SP, a. s.

Nasledovný krok aplikácie metodiky BSC spočíva vo vypracovaní klúčových HR indikátorov (KPI - Key Performance Indicators) pre hodnotenie strategických ciel'ov. Prehl'ad navrhnutých indikátorov ponúka tab. 1.

Tab. 1: Stanovenie klúčových HR indikátorov (KPI)

\begin{tabular}{|c|c|c|}
\hline Perspektíva & Ciele & Kl'účové HR indikátory (KPI) \\
\hline \multirow{13}{*}{ Financie } & \multirow{4}{*}{ Zvýšit' nákladovú účinnost' l'udských zdrojov } & Rozpočtové vs. skutočné náklady \\
\hline & & Zisk na zamestnanca \\
\hline & & Osobné náklady na zamestnanca \\
\hline & & $\begin{array}{l}\text { Podiel osobných nákladov na celkových } \\
\text { nákladoch }\end{array}$ \\
\hline & \multirow[t]{2}{*}{ Zvýšit' efektívnost' l'udských zdrojov } & $\begin{array}{l}\text { Návratnost' investící do l'udského } \\
\text { kapitálu (HC ROI - Human Capital } \\
\text { Return of Investment) }\end{array}$ \\
\hline & & Pridaná hodnota na zamestnanca \\
\hline & \multirow{3}{*}{ Zvyšovat' produktivitu práce } & Produktivita práce z výnosov \\
\hline & & Mzdová produktivita \\
\hline & & Osobné náklady/Výnosy \\
\hline & \multirow{4}{*}{$\begin{array}{c}\text { Zníženie rozdielu medzi priemernou mesačnou } \\
\text { mzdou v SP, a. s., a priemernou mesačnou } \\
\text { mzdou v hospodárstve SR }\end{array}$} & Mzdové prostriedky \\
\hline & & Priemerná mzda \\
\hline & & Štruktúra priemernej mzdy \\
\hline & & Mzdová rentabilita \\
\hline
\end{tabular}




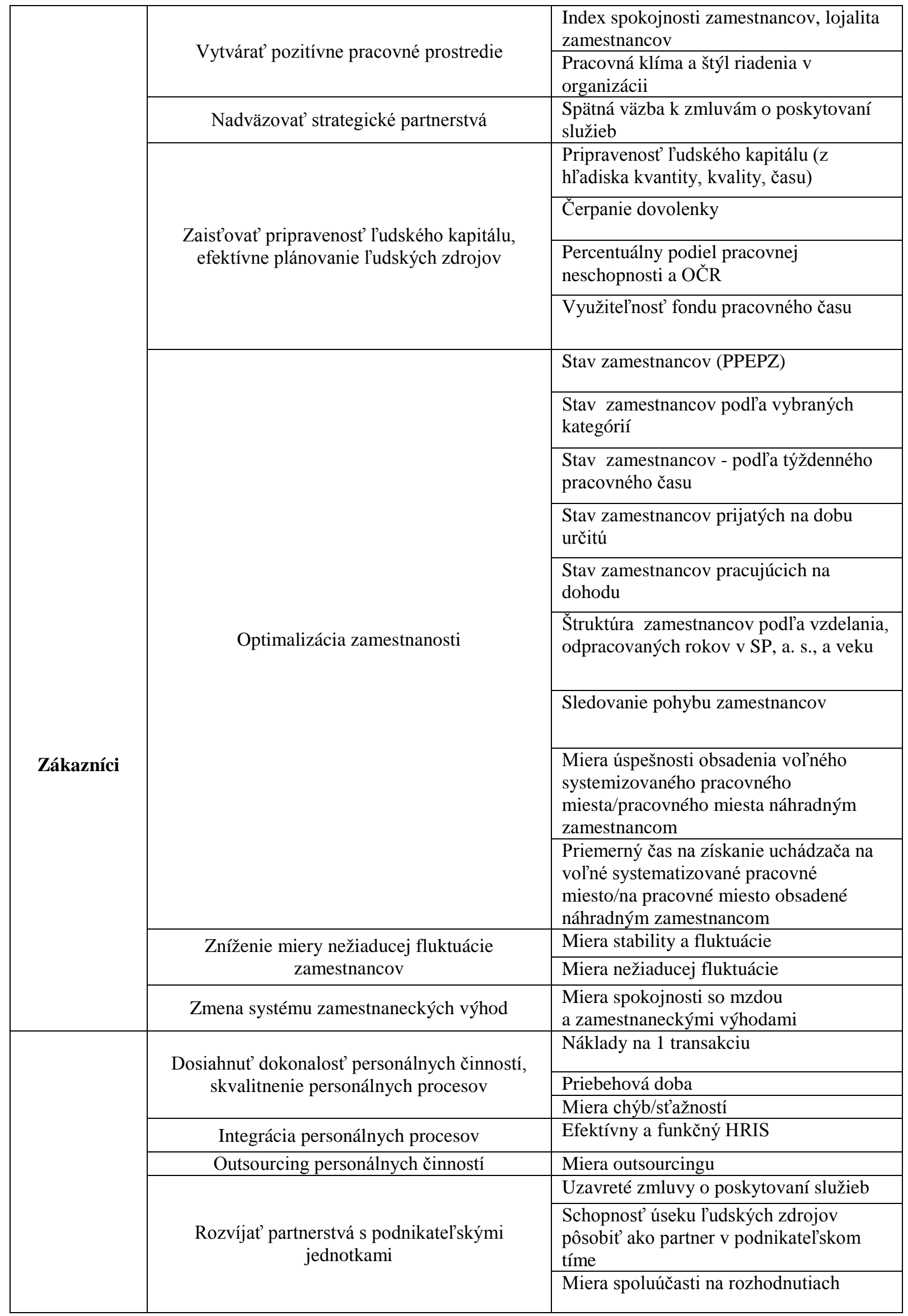




\begin{tabular}{|c|c|c|}
\hline \multirow[t]{26}{*}{$\begin{array}{l}\text { Interné } \\
\text { procesy }\end{array}$} & \multirow{7}{*}{ Zvýšenie kvality a úrovne služieb úseku LZZ } & $\begin{array}{l}\text { Kvalita poskytovaných rád z hl'adiska } \\
\text { toho, či zodpovedajú povahe problémov } \\
\text { (jasnost', presvedčivost'), praktická } \\
\text { využitel'nost' doporučení }\end{array}$ \\
\hline & & $\begin{array}{l}\text { Rýchlost' reakcie na požiadavky o rady } \\
\text { a služby }\end{array}$ \\
\hline & & $\begin{array}{l}\text { Rýchlost' prejednávania st’ažností } \\
\text { a odvolaní }\end{array}$ \\
\hline & & Čas venovaný zákazníkovi \\
\hline & & $\begin{array}{l}\text { Počet zamestnancov na jedného } \\
\text { personalistu }\end{array}$ \\
\hline & & Náklady úseku l’udských zdrojov \\
\hline & & Priemerná odmena personalistu \\
\hline & \multirow{5}{*}{$\begin{array}{l}\text { Poskytovat' strategickú podporu podnikatel'ským } \\
\text { jednotkám - rozvíjat' spôsobilosti zamestnancov }\end{array}$} & Pripravenost' l'udského kapitálu \\
\hline & & Pochopenie strategických ciel'ov podniku \\
\hline & & $\begin{array}{l}\text { Predpovedanie potrieb podniku } \\
\text { a manažmentu }\end{array}$ \\
\hline & & Uplatňované strategické plány úseku L’Z \\
\hline & & $\begin{array}{l}\text { Pomoc manažérom pri identifikácii } \\
\text { a zabezpečení potrieb vzdelávania }\end{array}$ \\
\hline & \multirow{6}{*}{$\begin{array}{l}\text { Príprava a rozvoj vedúcich pracovníkov a rozvoj } \\
\text { kultúry podpory }\end{array}$} & Systémové vyladenie vedenia \\
\hline & & Systémové vyladenie kultúry \\
\hline & & $\begin{array}{l}\text { Existencia príležitostí pre vzdelávanie } \\
\text { a rozvoj }\end{array}$ \\
\hline & & $\begin{array}{l}\text { Stupeň uplatnenia ich kvalifikácie } \\
\text { a schopností pri práci }\end{array}$ \\
\hline & & Miera kariérneho rozvoja \\
\hline & & Povýšenie talentov \\
\hline & \multirow{5}{*}{$\begin{array}{c}\text { Vytvorit’ organizáciu s vysokou výkonnost’ou, } \\
\text { zvýšenie efektívnosti systému riadenia } \\
\text { pracovného výkonu }\end{array}$} & Systémové vyladenie zamestnancov \\
\hline & & $\begin{array}{l}\text { Hodnotenie kvality procesu hodnotenia } \\
\text { pracovného výkonu pracovníkov }\end{array}$ \\
\hline & & $\begin{array}{l}\text { Hodnotenie reakcií užívatel'ov } \\
\text { (manažérov a jednotlivcov) }\end{array}$ \\
\hline & & $\begin{array}{l}\text { Analýza výstupov systému z hl'adiska } \\
\text { plánov rozvoja a zdokonal'ovania }\end{array}$ \\
\hline & & $\begin{array}{l}\text { Vplyv programu na motiváciu, výkon a } \\
\text { oddanost' }\end{array}$ \\
\hline & Zlepšenie internej komunikácie & $\begin{array}{l}\text { Miera informovanosti o pracovných } \\
\text { a zamestnaneckých záležitostiach }\end{array}$ \\
\hline & Poskytovat' strategické informácie & Pripravenost' systému aplikácií HR \\
\hline & Rozvíjat' strategické spôsobilosti & Spôsobilost'v oblasti l'udských zdrojov, \\
\hline
\end{tabular}




\begin{tabular}{|c|c|c|}
\hline \multirow{20}{*}{ Učenie a rast } & & $\begin{array}{l}\text { rozvoj kariéry, vnútorný personálny } \\
\text { marketing }\end{array}$ \\
\hline & $\begin{array}{l}\text { Zaistit' dostatok kvalitných vedúcich } \\
\text { pracovníkov l'udských zdrojov }\end{array}$ & Podrobná schéma kl'účových funkcií \\
\hline & $\begin{array}{l}\text { Vytvorit' zdiel'anú víziu a kultúru, zmena } \\
\text { firemnej kultúry }\end{array}$ & Strategické povedomie \\
\hline & Zvyšovat' angažovanost' zamestnancov & Motivácia k tvorivosti \\
\hline & $\begin{array}{l}\text { Rozšírit' preberanie najlepších praktických } \\
\text { postupov }\end{array}$ & Prevzaté najlepšie praktiky \\
\hline & \multirow{4}{*}{$\begin{array}{l}\text { Optimalizácia nákladov na vzdelávanie } \\
\text { zamestnancov }\end{array}$} & Náklady na školenia \\
\hline & & Náklady na interné školenia \\
\hline & & Náklady na externé školenia \\
\hline & & $\begin{array}{l}\text { Využívanie externých zdrojov (Fondy } \\
\text { EÚ) }\end{array}$ \\
\hline & \multirow{7}{*}{ Transformácia procesu vzdelávania } & Počet hodín školení \\
\hline & & Hodiny interných školení \\
\hline & & Hodiny externých školení \\
\hline & & Penetrácia školení \\
\hline & & Index jazykových kurzov \\
\hline & & Mobilita talentov \\
\hline & & $\begin{array}{l}\text { Stupeň, v akom programy vzdelávania } \\
\text { a rozvoja zodpovedajú potrebám podniku } \\
\text { i jednotlivcov }\end{array}$ \\
\hline & \multirow{4}{*}{ Podpora inovácií } & Počet podaných inovatívnych projektov \\
\hline & & $\begin{array}{l}\text { Pomer počtu obdržaných návrhov } \\
\text { k celkovému počtu zamestnancov }\end{array}$ \\
\hline & & $\begin{array}{l}\text { Počet využitel'ných návrhov od krúžkov } \\
\text { kvality alebo zlepšovatel'ských skupín }\end{array}$ \\
\hline & & $\begin{array}{l}\text { Úspory nákladov vzniknuté na základe } \\
\text { návrhov a doporučení krúžkov kvality }\end{array}$ \\
\hline
\end{tabular}

Pri vypracovaní kl’účových HR indikátorov (KPI - Key Performance Indicators) pre hodnotenie strategických ciel'ov boli použité jednotlivé diagnostické nástroje, ktoré sa v súčasnosti využívajú v SP, a. s. pri riadení l'udských zdrojov. Boli použité výstupy personálneho controllingu, špecializovaného auditu l'udských zdrojov, interného a externého benchmarkingu a personálneho marketingu.

Postup nasadenia metodiky BSC končí návrhom strategických programov, akčných plánov a súborom opatrení. Ich špecifikácia je súčastou metodického postupu (plánu) implementácie stratégie riadenia l'udských zdrojov v poštovom podniku.

\section{Záver}

Pri definovaní ciel'ov strategického riadenia l’udských zdrojov je nevyhnutné zvážit', do akej miery by stratégia l’udských zdrojov mala brat' do úvahy záujmy všetkých strán zainteresovaných na organizácii, teda záujmy pracovníkov, vlastníkov a manažmentu. „Mäkké strategické riadenie l’udských zdrojov“ bude klást' v riadení l'udských zdrojov dôraz na stránku l'udských vzt'ahov, na nepretržitý rozvoj, komunikáciu, zapájanie pracovníkov do rozhodovania, istotu zamestnania, kvalitu pracovného života, etické aspekty a vyváženost' pracovného a mimopracovného života. „Tvrdé strategické riadenie zdrojov“ na druhej strane bude klást' dôraz na úžitok, ktorý podniku prinesú investície do l'udských zdrojov v záujme podniku. To je zároveň filozofia riadenia l'udského kapitálu. Strategické riadenie by sa malo pokúšat' dosahovat' rovnováhu medzi tvrdými a mäkkými prvkami. Problém je však v tom, že 
mnohé podniky majú spravidla sklon uprednostňovat' tvrdý prístup a ponechávat' prvky mäkké prístupu stranou. Správne nastavenie kl'účových HR indikátorov v rámci uplatnenia metodiky BSC umožňuje riadit' úsek l'udských zdrojov podl'a podnikatel'ských princípov a vyhodnocovat' jeho príspevok $\mathrm{k}$ úspešnosti celej firmy.

\section{Literatúra}

[1] BÁČA, D.: Balanced scorecard: Ako prepojit’ stratégiu s každodennost'ou. 2004. Dostupné na internete: (http://podnikanie.etrend.sk/34368/riadenie-a-kariera/balancedscorecard-ako-prepojit-strategiu-s-kazdodennostou)

[2] KAPLAN, R.S., NORTON, D.P.: Balanced Scorecard: Strategický systém měření výkonnosti podniku. 4.vyd. Praha: Management Press, 2005, ISBN 80-7261-124-0

[3] STRENITZEROVÁ, M.: New trends of strategic management [Nové trendy strategického manažmentu] In: TRANSCOM 2005 : 6-th European Conference of Young Research and Science Workers in Transport and Telecommunications : Žilina, 27-29 June 2005 : proceedings. Section 2: Economics and Management. Part 2. - Žilina: University of Žilina, 2005. - ISBN 80-8070-414-7. - S. 159-163

[4] STRENITZEROVÁ, M.: The Development of Strategic Management In: Komunikácie Vedecké listy Žilinskej univerzity (Communications - Scientific Letters of the University of Žilina), 4/2005, ISSN 1335-4205 